\title{
KEPATUHAN HUKUM PEMBAYARAN PAJAK HOTEL DAN RESTORAN DALAM PENCAPAIAN TARGET PEMBANGUNAN
}

\author{
Fuadi, Andi Rachmad, Zaki Ulya \\ Fakultas Hukum, Universitas Samudra, Kota Langsa \\ fuadi@unsam.ac.id
}

\begin{abstract}
Abstrak
Pajak hotel dan restoran merupakan salah satu wajib pajak yang dibebankan untuk membayar pajak. Dasar hukum yang mengatur pembayaran pajak hotel dan restoran diakomodir dalam Qanun Kota Langsa No. 9 Tahun 2010 tentang Pajak Hotel dan Restoran. Dalam muatan pengaturannya, disimpulkan bahwa mekanisme pembayaran pajak hotel dan restoran oleh wajib pajak yaitu menggunakan mekanisme self asessment atau pembayaran sendiri, yang artinya bahwa setiap wajib pajak diwajibkan membayar sendiri secara langsung pajak yang dibebankan ke kas daerah. Dengan penerapan self asessment maka tentunya wajib pajak dituntut pula untuk menghitung sendiri perhitungan pajaknya yang akan dibayarkan. Metode yang digunakan dalam penulisan ini adalah metode penelitian hukum normatif. Hasil penelitian menunjukkan tingkat kepatuhan wajib pajak hotel setelah jatuh tempo pembayaran pajak masih minim. Sungguhpun pihak Dinasi Pendapatan Kekayaan dan Aset Kota Langsa telah menghitung perhitungan awal potensi penghasilan daerah yang bersumber dari pajak hotel dan restoran cukup besar. Faktor penyebab beberapa wajib pajak hotel tidak tepat waktu melakukan pembayaran dengan mekanisme self asessment adalah kurangnya omzet penghasilan yang diraih oleh pihak hotel. Sehingga pada saat dilakukan pendataan pajak hingga pembayaran pajak pada saat jatuh tempo tidak dilaksanakan.
\end{abstract}

Kata kunci: Kepatuhan Hukum; Pajak Hotel Restoran; Pendapatan Daerah. 


\title{
LAW COMPLIANCE WITH HOTEL AND RESTAURANT TAX PAYMENT IN THE ACHIEVEMENT OF DEVELOPMENT TARGETS
}

\begin{abstract}
Hotel and restaurant tax is one of the taxpayers who are charged to pay taxes. The legal basis governing hotel and restaurant tax payments is accommodated in Langsa City Qanun No. 9 of 2010 concerning Hotel and Restaurant Taxes. In the contents of the arrangement, it was concluded that the tax payment mechanism for hotels and restaurants by taxpayers is using a self-assessment mechanism, which means that each taxpayer is required to pay himself directly the taxes charged to the local treasury. With the application of self-assessment, of course, taxpayers are also required to calculate their own tax calculations to be paid. The method used in this paper is a normative legal research method. The results showed the level of compliance of hotel taxpayers after the due date of tax payments is still minimal. Even though the Langsa City Wealth and Assets Income Department has calculated the initial calculation of regional income potential sourced from hotel and restaurant taxes. The factor causing some hotel taxpayers to not make payments on self-assessment mechanism is the lack of income earned by the hotel. So that at the time of tax collection until tax payments at maturity are not carried out.
\end{abstract}

Keywords: Legal Compliance; Hotel and Restaurant Taxes; Regional Revenue. 
e-ISSN : 2621-4105

\section{A. PENDAHULUAN}

Anggaran daerah merupakan rencana keuangan yang menjadi dasar dalam pelaksanaan pelayanan publik. Di Indonesia, dokumen anggaran daerah disebut Anggaran Pendapatan dan Belanja Daerah (APBD), baik untuk provinsi maupun kabupaten dan kota. Penyusunan Anggaran Pendapatan dan Belanja Daerah diawali dengan membuat kesepakatan antara eksekutif dan legislatif tentang Kebijakan Umum Anggaran Pendapatan dan Belanja Daerah serta Prioritas dan Plafon Anggaran (PPA) yang akan menjadi pedoman untuk penyusunan anggaran pendapatan dan anggaran belanja. ${ }^{1}$

Pengertian PAD berdasarkan Pasal 1 angka 18 Undang-Undang Nomor 33 Tahun 2004 tentang Perimbangan Keuangan Antara Pusat dan Daerah bahwa: "Pendapatan asli daerah, selanjutnya disebut PAD adalah pendapatan yang diperoleh daerah yang dipungut berdasarkan peraturan daerah sesuai dengan peraturan perundang-undangan”. PAD merupakan tulang punggung pembiayaan daerah, oleh karenanya kemampuan melaksanakan ekonomi diukur dari besarnya kontribusi yang diberikan oleh PAD terhadap APBD, semakin besar kontribusi yang dapat diberikan oleh PAD terhadap APBD berarti semakin kecil ketergantungan pemerintah daerah terhadap bantuan pemerintah pusat. $^{2}$

Perekonomian daerah dapat berkembang pesat apabila sektor PAD juga mencukupi sesuai dengan target pencapaian pertahun yang dialokasikan untuk kebutuhan masyarakat. Berdasarkan Pasal 1 butir 15 Undang-undang Nomor 23 Tahun 2014 tentang Pemerintahan Daerah yang dimaksud dengan Pendapatan Daerah adalah semua hak daerah yang diakui sebagaimana penambahan nilai kekayaan bersih dalam priode tahun anggaran yang bersangkutan. ${ }^{3}$ Sesuai dengan ketentuan pasal 6 Undang-Undang Nomor 33 Tahun 2004 tentang Perimbangan Keuangan Antara Pusat dan Daerah menyebutkan bahwa: Pendapatan Asli Daerah dapat di peroleh melalui sumber-sumber dana yang di dapat dari Pajak Daerah, Retribusi Daerah, hasil pengelolahan kekayaan daerah yang dipisahkan. Sumber-sumber pendapatan tersebut diharapkan menjadi sumber pembiyaan

\footnotetext{
${ }^{1}$ Yani Rizal, "Pengaruh Pendapatan Asli Daerah, Dana Alokasi Umum dan Dana Alokasi Khusus Terhadap Alokasi Belanja Modal Daerah Kota Langsa”, Jurnal Samudra Ekonomi dan Bisnis 8 (1), 2017, hal. 634. DOI: https://doi.org/10.33059/jseb.v8i1

${ }^{2}$ Mardiasmo, "Otonomi dan Manajemen Keuangan Daerah", ANDI, 2004, Yogyakarta. hal. 6

${ }^{3}$ Lucia Rita Indrawati, et., al., "Perspektif Pajak Daerah Bagi Pendapatan Asli Daerah Kota Magelan”, Jurnal Riset Ekonomi Pembangunan 2 (1), 2017, hal. 142 (DOI: 10.31002/rep.v2i2.229)
} 
e-ISSN : 2621-4105

penyelenggaraan dan pembangunan untuk meningkatkan dan memeratakan kesejahteraan rakyat. Pada intinya PAD disetiap daerah bersumber pada pajak daerah, retribusi daerah dan hasil lainnya yang diperoleh oleh daerah sendiri. ${ }^{4}$

Salah satu sumber PAD adalah pajak daerah yang memiliki kontribusi yang sangat penting dalam membiayai pemerintahan dan pembangunan daerah karena pajak daerah bermanfaat dalam meningkatkan kemampuan penerimaan PAD dan juga mendorong laju pertumbuhan ekonomi daerah sehingga pajak daerah memiliki peran yang relatif penting sebagai salah satu sumber utama penerimaan keuangan daerah dalam komponen PAD dan membuatnya menjadi bagian yang sangat vital. ${ }^{5}$

Namun meskipun demikian, dalam hal kepatuhan masyarakat membayar pajak belum bisa dikatakan maksimal karena masih terdapat berbagai permasalahan dalam penagihan dan pembayarannya, dimana masih ada wajib pajak yang tidak menunjukkan kepatuhan dalam membayar pajak, seperti masih adanya keterlambatan bahkan ada yang masih belum melakukan kewajibannya tersebut. Pemerintah setempat kerap kali mengingatkan masyarakat untuk senantiasa melunasi utang pajaknya tepat waktu, namun upaya tersebut belum menunjukkan hasil yang optimal.

Penelitian sebelumnya tentang kepatuhan hukum pembayaran pajak hotel dan restoran pernah dikaji oleh Mika Trisnawati (2015) yang berjudul “Analisis Faktor-Faktor Yang Mempengaruhi Kepatuhan Wajib Pajak Membayar Pajak Hotel, Pajak Restoran Dan Pajak Hiburan Di Kota Denpasar”, penelitian ini fokus mengkaji tentang faktorfaktor yang mempengaruhi kepatuhan wajib pajak membayar pajak hotel, pajak restoran dan pajak hiburan di Kota Denpasar. Hasil penelitian ini menunjukkan bahwa pengetahuan pajak, kualitas pelayanan dan pemeriksaan pajak berpengaruh positif terhadap kesadaran wajib pajak membayar pajak hotel, pajak restoran dan pajak hiburan di Kota Denpasar; sedangan pengetahuan pajak tidak berpengaruh signifikan secara tidak langsung terhadap kepatuhan wajib pajak melalui kesadaran wajib pajak. Sedangkan kualitas pelayanan, dan pemeriksaan pajak berpengaruh signifikan secara tidak langsung

\footnotetext{
${ }^{4}$ Pengaturan mengenai pajak dan retribusi daerah selain diatur dalam Undang-Undang No. 33 Tahun 2004 juga mengacu pada regulasi khusus yaitu Undang-Undang Nomor 28 Tahun 2009 tentang Pajak Daerah dan Retribusi Daerah

${ }^{5}$ Imam Soebechi, “Judicial Review Peraturan Daerah Pajak dan Retribusi Daerah”., Sinar Grafika, 2012, Jakata, hal. 61
} 
terhadap kepatuhan wajib pajak melalui kesadaran wajib pajak membayar pajak hotel, pajak restoran dan pajak hiburan di Kota Denpasar. ${ }^{6}$

Penelitian selanjutnya oleh Ni Made Intan Priliandani dan Komang Adi Kurniawan Saputra (2019) yang berjudul "Pengaruh Norma Subjektif Dan Sosialisasi Perpajakan Terhadap Kepatuhan Wajib Pajak Hotel Dan Restoran”. Penelitian ini fokus mengkaji bagaimana pengaruh norma subjektif, dan sosialisasi perpajakan apakah berpengaruh terhadap kepatuhan wajib pajak hotel dan restoran di Kota Denpasar. Hasil penelitian ini menunjukkan bahwa norma subjektif dan sosialisasi perpajakan berpengaruh positif terhadap kepatuhan wajib pajak hotel dan restoran di Kota Denpasar. ${ }^{7}$

Sedangkan penelitian oleh Yanto dan kawan-kawan (2020) dengan judul "Pengaruh Pemeriksaan Pajak, Omset, Dan Sanksi Perpajakan Terhadap Kepatuhan Wajib Pajak Hotel Dan Restoran Di Kabupaten Jepara”. Penelitian ini fokus mengkaji bagaimana pengaruh pemeriksaan pajak, omset, dan sanksi perpajakan terhadap kepatuhan wajib pajak hotel dan restoran di Kabupaten Jepara. Hasil yang diperoleh di penelitian ini adalah bagaiman proses pemeriksaan pajak berpengaruh positif signifikan terhadap kepatuhan wajib pajak hotel dan restoran di Kabupaten Jepara. Adanya sanksi perpajakan berpengaruh positif signifikan terhadap kepatuhan wajib pajak hotel dan restoran di Kabupaten Jepara. Selain itu omzet yang diperoleh wajib pajak tidak berpengaruh terhadap kepatuhan pembayaran pajak hotel dan restoran. ${ }^{8}$

Perbedaaan penelitian ini dengan penelitian tentang kepatuhan pembayaran pajak daerah adalah bahwa penelitian ini lebih menonjolkan tentang kesadaran hukum wajib pajak dalam kepatuhan pembayaran pajak hotel dan restoran. Disamping itu penelitian ini juga meneliti tentang Self Assessment System sebagai upaya meningkatkan kepatuhan hukum pembayaran pajak hotel dan restoran di Kota Langsa. Tujuan dari kajian ini adalah hendak menelusuri tingkatan kepatuhan hukum masyarakat dalam pembayaran pajak dan mengkaji kaitannya pajak daerah dalam hal sebagai sarana menunjang sektor PAD untuk kepentingan pembangunan.

\footnotetext{
${ }^{6}$ Mika Trisnawati, Wayan Sudirman, "Analisis Faktor-Faktor Yang Mempengaruhi Kepatuhan Wajib Pajak Membayar Pajak Hotel, Pajak Restoran Dan Pajak Hiburan Di Kota Denpasar”, E-Jurnal Ekonomi dan Bisnis Universitas Udayana 4.12, 2015, hal. 975-999.

${ }^{7}$ Ni Made Intan Priliandani, Komang Adi Kurniawan Saputra, "Pengaruh Norma Subjektif Dan Sosialisasi Perpajakan Terhadap Kepatuhan Wajib Pajak Hotel Dan Restoran”, Jurnal KRISNA: Kumpulan Riset Akuntansi 11 (1), 2019, hal 13-25. DOI: https://doi.org/10.22225/kr.11.1.1158.13-25

${ }^{8}$ Yanto, Fatchur Rohman, Intan Ramadhanty, "Pengaruh Pemeriksaan Pajak, Omset, Dan Sanksi Perpajakan Terhadap Kepatuhan Wajib Pajak Hotel Dan Restoran Di Kabupaten Jepara", (2020) Jurnal KRISNA: Kumpulan Riset Akuntansi 11 (1), 2019, hal 13-25. DOI: https://doi.org/10.22225/kr.11.1.1158.13-25
} 
e-ISSN : 2621-4105

\section{B. PERUMUSAN MASALAH}

Berdasarkan uraian di atas, maka dapat ditentukan beberapa rumusan masalah diantaranya:

1) Bagaimana tingkat kepatuhan hukum wajib pajak hotel dan restoran di Kota Langsa dalam pembayaran pajak daerah dikaitkan dengan pembangunan daerah?

2) Faktor apasaja yang menyebabkan kepatuhan hukum wajib pajak hotel dan restoran sangat kurang dalam melakukan pembayaran pajak daerah?

3) Bagaimana realisasi PAD dari pajak hotel dan restoran dalam kaitannya dengan pembangunan daerah?

\section{METODE PENELITIAN}

Metode yang digunakan dalam penulisan ini adalah metode penelitian hukum normatif dengan data sekunder yaitu buku dan jurnal serta peraturan dan didukung oleh data primer, kemudian dianalisis secara deskriptif. Selain itu juga digunakan metode penelitian empiris dengan melihat data dan fakta di lapangan. ${ }^{9}$

\section{HASIL DAN PEMBAHASAN}

\section{Tingkat Kepatuhan Hukum Wajib Pajak Hotel Dan Restoran Di Kota Langsa Dalam Pembayaran Pajak Daerah Dikaitkan Dengan Pembangunan Daerah}

Dalam upaya memperbesar peran pemerintah daerah dalam pembangunan, pemerintah daerah dituntut untuk lebih mandiri dalam membiayai kegiatan operasional rumah tangganya. Berdasarkan hal tersebut dapat dilihat bahwa pendapatan daerah tidak dapat dipisahkan dengan belanja daerah, karena adanya saling terkait dan merupakan satu alokasi anggaran yang disusun dan dibuat untuk melancarkan roda pemerintahan daerah. ${ }^{10}$

Otoritas penyelenggaraan daerah dan pengelolaan APBD diatur lebih lanjut secara umum dalam Undang-Undang Nomor 23 Tahun 2014 tentang Pemerintahan Daerah dan juga mengacu pada Undang-Undang Nomor 33 Tahun 2004 tentang Perimbangan Keuangan Antara Pusat dan Daerah. Namun penyelenggaraan pemerintahan daerah di Aceh secara khusus diatur dalam Undang-Undang Nomor 11 Tahun 2006 tentang Pemerintahan Aceh. Sehingga Pemerintah Aceh mengatur secara khusus mengenai PAD salah satunya pengaturan tentang pajak daerah yang diakomodir dalam Qanun Aceh

\footnotetext{
${ }^{9}$ Peter Mahmud Marzuki, "Penelitian Hukum”, Kencana, 2007, Jakarta, hal 47.

${ }^{10}$ Andrian Sutedi, "Hukum Pajak", Sinar Grafika. 2011, Jakarta, hal. 15.
} 
Nomor 2 Tahun 2012 tentang Pajak Aceh. ${ }^{11}$ Qanun Aceh Nomor 2 Tahun 2012 tersebut dijadikan sebagai payung hukum dalam penetapan regulasi qanun kabupaten/kota tentang pengaturan pajak daerah.

Berdasarkan Peraturan Pemerintah Republik Indonesia Nomor 91 Tahun 2010 tentang Jenis Pajak Daerah yang Dipungut Berdasarkan Penetapan Kepala Daerah atau Dibayar Sendiri oleh Wajib Pajak, pajak terdiri atas pajak provinsi dan pajak kabupaten/kota. Pajak hotel dan pajak restoran termasuk dalam jenis pajak yang pemungutan atau pembayarannya dilakukan dengan sistem dibayar sendiri (self assessment). Hal ini sesuai dengan Pasal 4, Peraturan Pemerintah Republik Indonesia Nomor 91 Tahun 2010 tentang Jenis Pajak Daerah yang Dipungut Berdasarkan Penetapan Kepala Daerah atau Dibayar Sendiri oleh Wajib Pajak.

Khusus untuk Kota Langsa, pengaturan pajak daerah diatur lebih lanjut dalam ketentuan Qanun Kota Langsa Nomor 4 Tahun 2012 tentang Pajak Daerah. Adapun jenis pajak daerah sebagaimana diatur dalam qanun ini terdiri dari:

a. pajak reklame;

b. pajak penerangan jalan;

c. pajak mineral bukan logam dan batuan;

d. pajak air tanah;

e. pajak sarang burung walet. ${ }^{12}$

Sebagaimana data yang diperoleh Tahun 2017, target PAD Kota Langsa sebesar Rp. 124.092.504.605, yang berasal dari pendapatan pajak daerah, hasil retribusi daerah, hasil pengelolaan kekayaan daerah yang dipisahkan, penerimaan zakat, infaq, sadaqah dan lain-lain pendapatan asli daerah yang sah. Untuk pendapatan pajak daerah sebesar Rp. 10.535.000.000, hasil retribusi daerah sebesar Rp. 6.239.063.550, hasil pengelolaan kekayaan daerah yang dipisahkan sebesar Rp. 518.845.242. Kemudian, penerimaan zakat, infaq dan sadaqah sebesar Rp. 2.100.000.000 dan lain-lain pendapatan asli daerah yang sah sebesar Rp. 104.699.595.813. ${ }^{13}$

Pemasukan pajak dengan jumlah tertentu sesuai dengan yang ditargetkan sebagai sebuah wadah yang berwenang dibidang perpajakan tentu saja memerlukan dukungan

\footnotetext{
${ }^{11}$ Berdasarkan ketentuan Pasal 1 angka 8 Qanun Aceh No. 2 Tahun 2012 menyebutkan bahwa Pajak Aceh adalah kontribusi wajib kepada Pemerintah Aceh yang terutang oleh orang pribadi atau badan yang bersifat memaksa berdasarkan peraturan perundang-undangan, dengan tidak mendapatkan imbalan secara langsung dan digunakan untuk keperluan Aceh bagi sebesar-besarnya kemakmuran rakyat.

${ }^{12}$ Lihat Pasal 2 Qanun Kota Langsa No. 4 Tahun 2012 tentang Pajak Daerah

13 "Tahun 2017, Target PAD Kota Langsa Sebesar Rp124.092.504.605", https://www.goaceh.co/berita/baca/2016/11/24/tahun-2017-target-pad-kota-langsa-sebesar-rp124092504605, diakses pada tanggal 14 Februari 2018
} 
e-ISSN : 2621-4105

dari pihak-pihak yang terkait dengan perpajakan tersebut. Pihak-pihak yang dimaksud adalah para aparat pajak dan wajib pajak selaku pembayar pajak. Dalam kondisi yang ideal kedua pihak tersebut memang harus saling bekerja sama, dalam arti positif, sehingga mampu memandang satu tujuan atas dipungutnya pajak yaitu untuk penyelenggaraan kepentingan pembiayaan negara. Namun dalam kenyataannya, kondisi ideal tersebut masih jauh dari apa yang diharapkan.

Novi Andriani dan Amin Purnawan dalam tulisannya menyebutkan bahwa Pendapatan Asli Daerah bersumber dari pajak daerah, retribusi daerah, hasil pengelolaan kekayaan daerah yang dipisahkan dan lain-lain pendapatan asli daerah yang sah. pendapatan asli daerah merupakan tingkat kemandirian suatu daerah. ${ }^{14}$ Kontribusi pajak dan retribusi daerah sangat penting dalam mendukung peningkatan PAD. Dengan diberlakukannya otonomi daerah maka memberikan peluang bagi pemeritah untuk menggali hasil kekayaan daerah yang bersumber dari PAD. Karena jika PAD meningkat setiap tahunnya maka pembangunan di daerah akan terlaksana dengan baik serta untuk menunjang keperluan daerah. ${ }^{15}$

Adanya kerja sama antara wajib pajak dengan aparat pajak di lapangan sebagian masih merupakan kerja sama yang tidak positif. Artinya bahwa, adanya kerja sama tersebut justru merupakan kerja sama untuk melakukan penghindaran pajak dan dimanfaatkannya keinginan wajib pajak tersebut oleh sebagian aparat pajak untuk mendapatkan keuntungan pribadi. ${ }^{16}$

Hal tersebut menunjukkan bahwa memang tingkat kepatuhan pajak sebagian wajib pajak masih rendah. Begitu juga dengan tingkat keprofesionalitasan sebagian aparat pajak. Kondisi memprihatinkan itulah yang kemudian menjadi salah satu persoalan, sehingga menciptakan jalan terjal bagi terpenuhinya target pemasukan pajak ke dalam kas daerah.

Di dalam sosiologi maka masalah kepatuhan terhadap kaedah-kaedah telah menjadi pokok permasalahan yang cukup banyak dibicarakan.yang pada umumnya menjadi pusat perhatian adalah-adalah basis-basis atau dasar-dasar dari pada kepatuhan tersebut.

\footnotetext{
${ }^{14}$ Novi Andriani, Amin Purnawan, "Eksistensi Pengaturan Pajak Daerah Dalam Meningkatkan Pendapatan Asli Daerah Di Pemerintah Provinsi Jawa Tengah", Jurnal Hukum Khaira Ummah 12 (1), 2017, hal. 60.

${ }^{15}$ Md. Krisna Arta Anggar Kusuma, Ni Gst. Putu Wirawati, "Analisis Pengaruh Penerimaan Pajak Daerah Dan Retribusi Daerah Terhadap Peningkatan PAD Se Kabupaten/Kota Di Provinsi Bali”, E-Jurnal Akuntansi Universitas Udayana 5 (3), 2013, hal. 574.

${ }^{16}$ Adhi Catur, Kepala Seksi Pengawasan dan Konsultasi IV, KPP Pratama Kota Langsa, wawancara, pada tanggal 11 Juli 2018 (diolah)
} 
e-ISSN : 2621-4105

Menurut Bierstedt, maka dasar-dasar kepatuhan hukum adalah: Indoctrianation (Indoktrinasi) ; Habituation (tempat tinggal) ; Utility (kegunaan) ; Group Identification (Identitas Kelompok). ${ }^{17}$

Pelaksanaan Self Assessment System dalam sistem perpajakan di Indonesia menuntut wajib pajak untuk aktif menghitung, melaporkan dan membayar sendiri jumlah pajak yang terhutang kepada negara. Artinya bahwa wajib pajak telah diberikan kepercayaan penuh oleh negara. Namun demikian, kepercayaan tersebut tidak serta merta diberikan begitu saja. Aparat pajak tetap memiliki peran dalam pelaksanaan perpajakan, yaitu peran dengan fungsi pelayanan, pembinaan atau penyuluhan, pengawasan dan penerapan sanksi. Fungsi-fungsi tersebut menjadikan aparat pajak berperan sebagai pelayan publik. Aparat pajak sebagai pelayan publik tentu saja harus mampu melayani wajib pajak dalam melaksanakan serangkaian proses pembayaran pajak. ${ }^{18}$

Dengan adanya beberapa kali perubahan pada sistem perpajakan nasional tersebut ternyata tidak merubah ciri dan corak sistim pemungutan pajak yang berlaku, yaitu sistem "self assessment", yang berarti bahwa wajib pajak diwajibkan menghitung, memperhitungkan dan membayar sendiri jumlah pajak yang seharusnya terutang sesuai dengan ketentuan peraturan perundang-undangan perpajakan yang berlaku, sehingga penentuan besarnya pajak yang terhutang berada pada Wajib Pajak sendiri.

Mampu melayani memiliki makna bahwa aparat pajak seharusnya dapat mempermudah wajib pajak dalam melakukan pembayaran pajak. Namun demikian, mempermudah tidak dapat diartikan sebagai sebuah kegiatan dengan makna negatif. Artinya bahwa dalam mempermudah wajib pajak untuk melaksanakan kewajibannya tersebut seorang aparat pajak tetap saja tidak dibenarkan untuk mempermudah dengan melanggar ketentuan-ketentuan yang ada. ${ }^{19}$

Pada dasarnya pemungutan pajak dari masyarakat harus dapat dikembalikan pula untuk masyarakat. Ini berarti bahwa apa yang telah dibayarkan oleh wajib pajak kepada negara pada akhirnya hasil dari pembayaran pajak tersebut harus dapat dinikmati kembali oleh masyarakat luas. ${ }^{20}$ Mahlil menambahkan dalam keterangannya bahwa Kepatuhan

${ }^{17}$ Ellya Rosana, "Kepatuhan Hukum Sebagai Wujud Kesadaran Hukum Masyarakat”, Jurnal TAPIs 10 (1), 2014. (https://doi.org/10.24042/tps.v10i1.1600)

${ }_{18}$ Adhi Catur, Kepala Seksi Pengawasan dan Konsultasi IV, KPP Pratama Kota Langsa, wawancara, pada tanggal 11 Juli 2018 (diolah)

${ }^{19}$ Mahlil, Kepala Bidang Pendapatan DPKA Kota Langsa, wawancara, pada tanggal 10 Juli 2018 (diolah)

${ }^{20}$ Mahlil, Kepala Bidang Pendapatan DPKA Kota Langsa, wawancara, pada tanggal 10 Juli 2018 (diolah) 
e-ISSN : 2621-4105

pajak tidak dapat dilepaskan dari tax ratio (rasio pajak), yang merupakan perbandingan penerimaan pajak dengan Produk Domestik Bruto (PDB). Rasio ini seringkali menjadi ukuran kinerja sektor perpajakan. Selanjutnya rasio tersebut juga digunakan untuk menilai tingkat kepatuhan pembayaran pajak oleh masyarakat. ${ }^{21}$

Tingkat kepatuhan wajib pajak hotel dan pajak restoran dalam membayar pajaknya tentunya dapat memiliki pengaruh positif signifikan terhadap self assessment system di Dinas Pendapatan Daerah Kota Langsa, sedangkan selebihnya dipengaruhi oleh faktor lain diluar yang diteliti (Pajak Bumi dan Bangunan, dan Penerimaan Pajak lainnya). Namun, realita yang ditemukan menyebutkan bahwa sejumlah wajib pajak hotel dan restoran masih kurang dalam melakukan pembayaran pajak.

Beberapa upaya yang dilakukan oleh Pemerintah Kota Langsa, dalam hal ini Dinas Pendapatan Kekayaan dan Aset Kota Langsa terkait penarikan pajak dari wajib pajak. Terkait pembayaran pajak hotel dan restoran di Kota Langsa, pihak Dinas Pendapatan Kekayaan dan Aset Kota Langsa melakukan inisiatif dengan mengirimkan petugas setiap malamnya ke hotel untuk menghitung jumlah tamu hotel yang menginap.

Kegiatan pembukuan dan pelaporan yang dilakukan oleh petugas merupakan kegiatan yang mana petugas atau pihak Dinas melakukan pembukuan terhadap penerimaan pajak/retribusi daerah dan pendapatan lainnya berupa pembukuan objek pajak yang sudah terdata dan ditetapkan sebagai wajib pajak. Sehingga dengan dilakukanya pembukuan tersebut petugas dapat menyusun target penerimaan dan mengevaluasi serta melaporkan realisasi penerimaan pajak pajak yang sudah terdata.

Berdasarkan pada data yang diperoleh oleh petugas tersebut akan dihimpun dalam bentuk perolehan dana yang diperkirakan akan menjadi penghasilan hotel dan menjadi nilai pajak. Petugas lapangan tersebut dapat datang dalam waktu semalam sekali maupun dua malam sekali. Hal yang sama juga diberlakukan terhadap restoran yang ada di Kota Langsa.

Objek Pajak Restoran adalah pelayanan yang disediakan oleh restoran. Pelayanan yang disediakan restoran meliputi pelayanan penjualan makanan dan/atau minuman yang dikonsumsi oleh pembeli, baik dikonsumsi di tempat pelayanan maupun di tempat lain. Perhitungan pajak restoran di Kota Langsa secara umum diletakkan pada jenis makanan maupun harga dari makanan yang disediakan.

${ }^{21}$ Mahlil, Kepala Bidang Pendapatan DPKA Kota Langsa, wawancara, pada tanggal 10 Juli 2018 (diolah) 
Pajak hotel dan pajak restoran termasuk dalam jenis pajak yang pemungutan atau pembayarannya dilakukan dengan sistem dibayar sendiri (self assessment). Hal ini sesuai dengan Pasal 4 Peraturan Pemerintah Republik Indonesia Nomor 91 Tahun 2010 tentang Jenis Pajak Daerah yang Dipungut Berdasarkan Penetapan Kepala Daerah atau Dibayar Sendiri oleh Wajib Pajak.

\section{Faktor Penyebab Kepatuhan Hukum Wajib Pajak Hotel Dan Restoran Sangat Kurang Dalam Melakukan Pembayaran Pajak Daerah}

Setelah diuraikan tingkat kepatuhan dalam kaitannya dengan substansi hukum menurut teori sistem hukum, maka selanjutnya melihat tatanan struktur hukumnya. Secara umum, Struktur hukum yaitu kerangka bentuk yang permanen dari sistem hukum yang menjaga proses tetap berada di dalam batas-batasnya. Kerangka yang dimaksud tersebut yaitu institusi-institusi yang mempunyai wewenang tertentu utuk menjalankan tugas sebagaimana dibebankan oleh keputusan/peraturan atau lainnya.

Pada tataran hukum, struktur hukum disamakan sebagai penegak hukum. Kewenangan lembaga penegak hukum dijamin oleh undang-undang. Sehingga dalam melaksanakan tugas dan tanggung jawabnya terlepas dari pengaruh kekuasaan pemerintah dan pengaruh-pengaruh lain. Hukum tidak dapat berjalan atau tegak bila tidak ada aparat penegak hukum yang kredibilitas, kompeten dan independen. Seberapa bagusnya suatu peraturan perundang-undangan bila tidak didukung dengan aparat penegak hukum yang baik maka keadilan hanya angan-angan. Lemahnya mentalitas aparat penegak hukum mengakibatkan penegakkan hukum tidak berjalan sebagaimana mestinya.

Selain struktur hukum (legal structure), dalam legal system theory juga dikenal dengan budaya hukum (legal culture). Menyimak dari pengaturan pajak hotel dan restoran di Kota Langsa diakomodir dalam Qanun Kota Langsa No. 9 Tahun 2010 yang mengatur prihal sanksi tidak terealisasi dengan baik, sehingga menimbulkan persepsi wajib pajak bahwa pembayaran pajak hotel maupun restoran bukanlah sebagai sebuah kewajiban mutlak.

Masalah kepatuhan hukum sebenarnya menyangkut proses internalisasi (internalization) dari hukum tersebut. Proses internalisasi dimulai pada saat seseorang dihadapkanpada pola perikelakuan baru sebagaimana diharapakan oleh hukum, pada 
e-ISSN : 2621-4105

suatu situasi tertentu. Awal dari pada proses inilah yang biasanya disebut sebagai proses belajar, dimana dimana terjadi suatu perubahan pada pendirian seseorang.yang esensial pada proses ini adalah adanya penguat terhadap respon yang diinginkan melalui imbalan dan hilangnya respon-respon terdahulu karena tidak adanya penguatan atau mungkin oleh adanya sanksi yang negative terhadap perikelakuan demikian. ${ }^{22}$

Selain mempengaruhi kepatuhan hukum wajib pajak, faktor lain adalah akan memunculkannya sebuah budaya hukum yang lalai akan ketaatan membayar pajak. Mahlil dan dikuatkan oleh Adhi Catur menyebutkan penyelesaian keterlambatan pembayaran pajak ditempuh cenderung digunakan mekanisme musyawarah secara kekeluargaan, sehingga efek dari keberlakuan qanun tersebut tidak dirasakan oleh wajib pajak. $^{23}$

Berdasarkan penelitian yang dilakukan dengan sejumlah responden dari hotel dan restoran di Kota Langsa, ditemukan beberapa penyebab pajak hotel dan restoran terlambat dibayarkan pada saat jatuh tempo. Namun, pengecualian atas Hotel Harmoni dan Hotel Kartika. Pada sesi wawancara yang dilakukan melalui admin kedua hotel menyebutkan bahwa pihak hotel Harmoni dan Hotel Kartika selalu melakukan pembayaran pajak tepat waktu. Hal ini tentunya konsumen yang menginap dan menggunakan jasa perhotelan dikedua hotel tersebut selalu aktif.

Selain itu, pihak pemerintah kota disatu sisi juga menggunakan jasa hotel dikedua hotel tersebut untuk melaksanakan kegiatan seminar dengan menyewa tempat berupa aula yang disediakan oleh hotel. Sehingga dari segi pendapatan hotel tentunya bertambah sehingga pada saat tempo pajak telah jatuh maka pembayaran dapat dilakukan.

Pada saat ditemui untuk dilakukan sesi wawancara di Hotel Ferla Inn Kota Langsa, menyatakan bahwa setiap malam hari pihak petugas dari pemerintah kota selalu datang melakukan pengecekan pada buku tamu dengan menghitung jumlah tamu hotel yang menginap di Hotel Ferla Inn. Prihal mekanisme pengecekan buku tamu yang dilakukan oleh petugas pemerintah kota telah diketahui sebelumnya saat sosialisasi yang dilakukan

${ }^{22}$ Atang Hermawan Usman, “ Kesadaran Hukum Masyarakat Dan Pemerintah Sebagai Faktor Tegaknya Negara Hukum Di Indonesia”, Jurnal Wawasan Hukum 30 (1), 2014, hal 27.

${ }^{23}$ Mahlil, Kepala Bidang Pendapatan DPKA Kota Langsa, wawancara, pada tanggal 10 Juli 2018 (diolah), dan dikuatkan oleh Adhi Catur, Kepala Seksi Pengawasan dan Konsultasi IV, KPP Pratama Kota Langsa, wawancara, pada tanggal 11 Juli 2018 (diolah) 
e-ISSN : 2621-4105

oleh Pemerintah Kota Langsa tentang pemberlakuan Qanun Kota Langsa No. 9 Tahun 2010 tentang Pajak Hotel dan Restoran. ${ }^{24}$

Terkait pembayaran pajak selama 2016-2017 pihak Hotel Ferla Inn selalu tepat waktu dalam membayar pajak dan tidak pernah terhutang pajak. Sebagai wajib pajak, tentunya pihak hotel sadar akan kewajibannya dalam melakukan pembayaran pajak. Mengingat Hotel Ferla Inn termasuk salah satu hotel mewah di Kota Langsa setelah Hotel Harmoni dan Hotel Kartika. Pembayaran dilakukan sendiri oleh manajer hotel ke pihak pemerintah Kota Langsa, dalam hal ini Dinas Pendapatan Kekayaan dan Aset Kota Langsa.

Namun dalam kurun waktu tahun 2018 ditemui beberapa kendala dalam melakukan pembayaran pajak hotel. Hal ini diakui manajer Hotel Ferla Inn yang menyebutkan bahwa Hotel Ferla Inn sedang melakukan renovasi bangunan sehingga membutuhkan banyak dana, dan dana yang digunakan adalah dana penghasilan yang diraih oleh Hotel dari pembayaran yang dilakukan oleh tamu yang menginap.

Selain itu, omzet hotel juga menurun drastis mengingat jumlah tamu hotel yang menginap di tahun 2018 sangat sedikit. Akibat turunnya omzet penghasilan hotel, Manajer Hotel Ferla Inn menuturkan bahwa keterlambatan pembayaran pajak diupayakan maksimal 2 bulan dan akan dibayar penuh dibulan ketiga. Terkait keterlambatan tersebut, pihak pemerintah kota sudah memberikan teguran kepada manajemen hotel untuk segera melakukan pembayaran. Namun, terkait sanksi dan denda administrasi akibat terlambat pembayaran pajak hotel, manajer Hotel Ferla Inn mengungkapkan tidak pernah diberikan sanksi maupun denda administrasi. ${ }^{25}$

Adapun hotel selanjutnya yang dilakukan penelitian adalah Hotel Ridho. Namun, pada saat audiensi dengan pihak hotel disebutkan bahwa manajer hotel tidak bersedia dimintai keterangan untuk kepentingan penelitian.

Penelitian kemudian dilanjutkan di Hotel Kartini milik Sekolah Menengah Kejuruan No. 3 (SMKN.3) Kota Langsa. Pada saat ditemui untuk dimintai keterangan dan data, kondisi Hotel Kartini sedang dalam proses renovasi. Sesi wawancara dilakukan dengan Kepala Sekolah didampingi penanggungjawab Hotel Kartini menyebutkan bahwa selama dalam masa waktu tahun 2018, Hotel Kartini sangat minim menerima tamu. Hal

\footnotetext{
${ }^{24}$ T. Zefrizal, Manajer Hotel Ferla Inn, wawancara, pada tanggal 12 Juli 2018 (diolah)

${ }^{25}$ T. Zefrizal, Manajer Hotel Ferla Inn, wawancara, pada tanggal 12 Juli 2018 (diolah)
} 
e-ISSN : 2621-4105

ini disebabkan tujuan dibangunnya hotel tersebut tidak lain adalah sebagai tempat praktek siswa bidang perhotelan. Sehingga jenis hotel Kartini bukanlah hotel komersil sebagaimana hotel lainnya.

Namun, apabila dikaitkan dengan omzet penghasilan Hotel Kartini tidak hanya bergantung pada tamu namun juga disubsidi oleh Pemerintah Kota Langsa melalui APBK. Muncul paradigma beragam terkait keberadaan hotel kartini, salah satunya adalah hotel tersebut merupakan aset/milik pemerintah kota di bawah naungan Dinas Pendidikan Kota Langsa. Kemudian dalam waktu dekat akan dilimpahkan kepemilikannya menjadi aset provinsi mengingat seluruh SMK se-Aceh menjadi tanggungjawab provinsi.

Akibat Hotel Kartini merupakan aset milik daerah dan dikaitkan dengan pembayaran pajak hotel tentunya sangat tidak lumrah. Namun, pihak hotel kartini tetap melakukan pembayaran pajak hotel sepanjang ada konsumen masyarakat yang menginap dihotel kartini. Berdasarkan data diperoleh, Hotel Kartini mempunyai fasilitas kamar sebanyak 9 kamar dan umumnya terisi 7 kamar apabila di Langsa diselenggarakan event tertentu.

Atas dasar Hotel Kartini lebih pada tujuan praktek siswa, maka petugas dari pihak Pemerintah Kota Langsa datang sebulan sekali. Dan terkait pembayaran pajak, pihak Hotel Kartini menuturkan pembayaran pajak secara self asessment dilakukan sendiri dengan membayar langsung ke Dinas Pendapatan Kekayaan dan Aset Kota Langsa. ${ }^{26}$

Adapun hasil penelitian yang dilakukan di Hotel Harmoni Kota Langsa, wawancara dilakukan dengan admin Hotel Harmoni. Sementara itu, manajer hotel sedang berada di luar daerah. Dalam penyampaiannya disebutkan bahwa Hotel Harmoni sepanjang tahun 2018 dalam kaitannya dengan pembayaran pajak selalu dilakukan secara self asessment pada saat jatuh tempo. Hotel Harmoni merupakan salah satu hotel program taat pajak sesuai program Pemerintah Kota Langsa. Hal ini terbukti dengan dipasangnya Baliho sebagai Hotel yang taat pajak. ${ }^{27}$

Banyaknya tamu yang menginap dan penyewaan aula untuk kegiatan acara baik oleh pemerintah kota maupun pihak lainnya, menjadikan omzet hotel meningkat. Sehingga pembayaran pajak hotel pun dapat dilakukan tepat waktu. Prihal yang sama juga dipaparkan oleh Admin Hotel Kartika dimana dalam beberapa sesi waktu tamu hotel

\footnotetext{
${ }^{26}$ Herna Yunita, Pengelola/Penanggungjawab Hotel Kartini SMKN 3 Kota Langsa, wawancara, pada tanggal 13 Juli 2018 (diolah)

${ }^{27}$ Imelda Diana Sari, Administrasi Hotel Harmoni, wawancara, pada tanggal 17 Juli 2018 (diolah)
} 
e-ISSN : 2621-4105

dalam kategori banyak dan sedang. Sedangkan penyewaan aula untuk kegiatan acara juga ada dilakukan sehingga omzet yang diraih hotel kartika mencukupi untuk dilakukannya pembayaran pajak hotel. ${ }^{28}$

Merujuk pada hasil penelitian pada hotel di Kota Langsa yang dipilih sebagai responden penelitian menunjukkan bahwa faktor kendala utama pembayaran pajak hotel tidak tepat waktu adalah faktor omzet penghasilan yang minim. Hal ini dirasakan oleh Hotel Ferla Inn, Hotel Kartini yang notabene sebagai hotel kecil di Kota Langsa. Keterlambatan pembayaran pajak sejak jatuh tempo maksimal rata-rata 2 (dua) bulan ataupun 3 (tiga) bulan.

Maka secara umum untuk seluruh uraian yang dipaparkan oleh responden maka kendala dalam pembayaran pajak diantaranya:

a. Wajib pajak belum mengetahui arti penting pajak, sehingga wajib pajak enggan membayar pajaknya kepada Dinas Pendapatan Pengelolaan Keuangan dan Aset Kota Langsa.

b. Belum adanya kesadaran wajib pajak dalam mematuhi peraturan daerah atau ketentuan yang telah ditetapkan, sehingga banyaknya wajib pajak yang melanggar peraturan tersebut.

c. Wajib pajak menipulasi pembayaran pajaknya, dalam hal ini pembayaran yang dia lakukan tidak sesuai dengan pendapatan atau omzet penjualan yang diperoleh.

d. Banyaknya penunggakan pajak yang dilakukan oleh wajib pajak itu sendiri.

e. Minimnya kesadaran wajib pajak untuk menyetor pajaknya sendiri ke Dinas Pendapatan Pengelolaan Keuangan dan Aset Kota Langsa.

Adapun untuk kategori pembayaran pajak restoran, pihak pemerintah Kota Langsa telah melakukan pendataan terkait jumlah Restoran, Rumah Makan dan Warung Kopi yang ada di Kota Langsa yang mempunyai orientasi penghasilan pajak. Sementara itu, responden yang dipilih dalam penelitian diantaranya: Cafe dan Resto Daun Kipas, CFC Langsa, Keysha Resto, Ayam Penyet Cabe Ijo, RM Asia Utama, Minang Kabau Restoran. Kecendrungannya, penarikan/pembayaran pajak restoran lebih sulit dari pada pembayaran pajak hotel. Hal ini dipaparkan oleh Mahlil bahwa restoran, rumah makan, maupun warung kopi yang menyediakan layanan jasa restoran cenderung tidak terduga. Disatu waktu terdata dalam catatan, disatu waktu lainnya akibat menderita kerugian, restoran tersebut tutup ditengah jalan. Sementara itu, pada pendataan awal restoran tersebut diduga dapat mempunyai potensi pajak yang cukup.

${ }^{28}$ Asrul Dedek, Administrasi Hotel kartika Langsa, wawancara, pada tanggal 16 Juli 2018 (diolah) 
e-ISSN : 2621-4105

Selain itu, setiap restoran tidak serta merta mencatat pajak dalam faktur pembayaran makanan oleh konsumen, sebagaimana bill hotel. Sehingga bisa jadi harga makanan terlampau tinggi sementara pajaknya tidak disisihkan sebagaimana persentase pajak yang seharusnya dipotong dari harga suatu makanan yang disediakan

\section{Realisasi PAD Dari Pajak Hotel Dan Restoran Dalam Kaitannya Dengan Pembangunan Daerah}

Dalam rangka menyelenggarakan rumah tangganya sendiri, pemerintah daerah memerlukan dana yang tidak sedikit. Oleh karena itu, pemerintah daerah harus mengoptimalkan sumber-sumber penerimaan daerah dalam era otonomi daerah dan desentralisasi fiskal. Berdasarkan Undang-Undang Nomor 33 Tahun 2004 tentang Perimbangan Keuangan antara Pemerintah Pusat dan Pemerintah Daerah, sumber penerimaan daerah terdiri dari $\mathrm{PAD}$, dana perimbangan, dan lainlain pendapatan daerah yang sah. PAD merupakan salah satu indikator yang menentukan derajat kemandirian suatu daerah. Komponen PAD itu sendiri terdiri dari pajak daerah, retribusi daerah, bagian laba usaha daerah, dan lain-lain PAD yang sah. ${ }^{29}$

Untuk mengetahui besarnya kontribusi penerimaan pajak hotel dan restoran dalam upaya peningkatan PAD Kota Langsa digunakan analisis kontribusi yaitu analisis yang digunakan untuk membandingkan antara realisasi pajak hotel dan restoran dengan realisasi PAD.

Tanggapan responden tentang pemungutan atau penagihan ini yaitu, bahwa prakteknya dilapangan tidak sesuai dengan ketentuan aturan daerah, dikarenakan kurangnya kesadaran wajib pajak untuk mau menyetorkan sendiri pajaknya kebadan yang telah ditunjuk oleh pemerintah, sehingga pihak Dinas Pendapatan Kekayaan dan Aset memungut langsung ke tempat wajib pajak melakukan usahanya.

Dengan berlakunya tarif pajak pajak dan restoran yang telah disepakati sebesar $10 \%$ maka keberhasilan untuk pencapaian target yang dimaksud tidaklah terletak ditangan Kepala Dinas Pendapatan Pengelolaan Keuangan dan Aset semata melainkan rangkaian kerjasama seluruh unit kerja yang ada dengan melaksanakan sistem kerja yang sudah disusun secara optimal.

Untuk mengetahui tarif pajak restoran dapat dilihat tanggapan responden dilapangan: Tanggapan responden tentang tarif pajak restoran yaitu sebesar $10 \%$ dari

${ }^{29}$ Saidi. M. Djafar Saidi, “Pembaruan Hukum Pajak”. PT Raja Grafindo Persada, 2011, Jakarta, hal. 41. 
e-ISSN : 2621-4105

Dasar Pengenaan Pajak, tetapi tarif ini nyatanya dilapangan tidak berjalan dengan semestinya. Dari tanggapan tersebut dapat diketahui bahwa tarif yang ditetapkan oleh Pemda dilapangan tidak berjalan dengan semestinya dikarenakan kurangnya pemahaman wajib pajak tentang pajak itu sendiri, sehingga dia menganggap bahwa pajak restoran itu terbeban pada dirinya sendiri, ini mengakibatkan wajib pajak enggan membayar pajak dan melakukan negosiasi pengurangan tarif dengan alasan omzetnya yang sedikit.

Pembagian pajak daerah ini dilakukan berdasarkan kewenangan pengenaan dan pemungutan masingmasing jenis pajak daerah pada wilayah administratif provinsi atau kabupaten/kota yang bersangkutan. Namun pajak daerah tersebut tidak semua terlaksana secara baik dan efesien. Hal ini dikarenakan di beberapa pemerintah daerah tersebut penerimaan yang potensial hanya bersumber dari beberapa jenis pajak saja, misalnya pajak hotel, pajak restoran, pajak hiburan atau pajak reklame saja. Pendapatan Asli Daerah merupakan "penerimaan dari pungutan pajak daerah, retribusi daerah, hasil dari perusahaan daerah, penerimaan dari dinasdinas dan penerimaan lainnya yang termasuk dalam Pendapatan Asli Daerah (PAD) yang bersangkutan, dan merupakan pendapatan daerah yang sah". Semakin tinggi peranan Pendapatan Asli Daerah (PAD) dalam pendapatan daerah merupakan cermin keberhasilan usaha-usaha atau tingkat kemampuan dalam pembiayaan penyelenggaraan pemerintahan dan pembangunan. ${ }^{30}$

Menyadari betapa pentingnya Pendapatan Asli Daerah (PAD) guna untuk membiayai belanja daerah dan pembangunan daerah khususnya di Kota Langsa. Berbagai upaya terus dilakukan termasuk usaha intensifikasi dan ekstensifikasi terhadap pemungutan Pendapatan Asli Daerah (PAD), yang mana upaya ini secara konsisten memungkinkan untuk meningkatkan penerimaan di sektor pajak hotel dan restoran di Kota Langsa.

Dinas Pendapatan Pengelolaan Kekayaan Asli Daerah selaku SKPD yang menangani penerimaan daerah khususnya Pajak, harus mempunyai data historis agar dalam menetukan target disetiap jenis pajak memiliki dasar penetapan targen. Sehingga dapat dilihat dan dihitung potensi pajak yang sebenarnya.

Dari hasil analisis kontribusi penerimaan pajak hotel terhadap peningkatan Pendapatan Asli Daerah (PAD) Kota Langsa masih tergolong rendah. Dilihat secara

${ }^{30}$ Ronald Bua Toding, “Analisis Potensi Dan Efektivitas Pemungutan Pajak Hotel Dalam Meningkatkan Pendapatan Asli Daerah Kota Palangka Raya”, Jurnal EMBA 4 (1), 2016, hal 214-222.

DOI: https://doi.org/10.35794/emba.v4i1.11588 
e-ISSN : 2621-4105

keseluruhan selama lima tahun terakhir rata-rata kontribusi pajak hotel pada peningkatan pendapatan asli daerah dikategorikan kurang memberikan kontribusi, karena presentase kontribusi sangat jauh dari angka $4 \%$. Kurangnya kontribusi pajak hotel disebabkan karena kurangnya jumlah unit hotel yang ada dan jenis hotel yang hanya berbintang 1 dan 2 saja. Dari hasil analisis kontribusi penerimaan pajak retoran terhadap peningkatan Pendapatan Asli Daerah (PAD) Kota Langsa tahun anggaran 2017-2018 dilihat secara keseluruhan rata-rata kontribusi yang diberikan Pajak Restoran pada Pendapatan Asli Daerah dikategorikan sangat mempunyai kontibusi karena presentase kontribusi diatas $4 \%$.

Merujuk pada data yang diperoleh dari DPKA Langsa dalam hal anggaran daerah yang bersumber dari pajak, khususnya hotel dan restoran mengalami peningkatan dari tahun 2017. Hal ini dibuktikan dengan data yang diperoleh berdasarkan persentase peningkatan anggaran daerah bersumber dari pajak dapat dilihat pada tabel di bawah:

\section{TABEL I}

\section{PENJABARAN LAPORAN REALISASI ANGGARAN PENDAPATAN DAN BELANJA DAERAH TAHUN ANGGARAN 2017}

\begin{tabular}{|l|l|c|c|c|c|}
\hline \multirow{2}{*}{ No. } & \multirow{2}{*}{ Uraian } & \multicolumn{2}{|c|}{ Jumlah } & \multicolumn{2}{c|}{ Bertambah/Berkurang } \\
\cline { 3 - 6 } & & Perubahan & Realisasi & $(\mathbf{R p})$ & $\mathbf{( \% )}$ \\
\hline & $\begin{array}{l}\text { PENDAPATAN } \\
\text { ASLI DAERAH }\end{array}$ & & & & \\
\hline 1. & Pajak Hotel & 500.000 .000 & 520.059 .282 & 20.059 .282 & 104,01 \\
\hline 2. & Pajak Restoran & 670.000 .000 & 820.572 .955 & 150.572 .955 & 122,47 \\
\hline & & $\ldots$ & $\ldots$ & $\ldots$ & $\ldots$ \\
\hline
\end{tabular}

Sumber: Dinas Pendapatan Kekayaan dan Aset Kota Langsa-2017

Merujuk pada Tabel I di atas, digambarkan pendapatan daerah dalam APBD Kota Langsa terkait pajak hotel dan restoran disatu sisi nominalnya meningkat drastis dari pada capaian potensi hasil pajak yang diperkirakan sebelumnya. Sungguhpun, persentase peningkatan diatas $100 \%$, namun dalam hal realisasi dengan aspek pembangunan belum terakomodir dengan baik, atau bahkan peran pajak hotel dan restoran dalam pembangunan sangat kecil.

Oleh sebab itu, Dinas Pendapatan Kekayaan dan Aset Kota Langsa harus menyiapkan tambahan aparatur pajak dalam satu tim untuk mengapdate data-data tagihan yang lebih akurat dan terbaru disetiap tahunnya, serta meningkatkan pemeriksaan dan 
e-ISSN : 2621-4105

kinerja lapangan. Peningkatan upaya pengoptimalan terhadap kualitas dan kuantitas pemungutan yang lebih efektif agar pencapaian kontribusi dan efektivitas dapat optimal untuk memenuhi keuangan daerah. Selain itu pemerintah harus lebih tegas dalam pengadaan sanksi hukum kepada wajib pajak yang tidak jujur atau enggan membayar ataupun mendaftarkan dirinya karena merasa pajak tidak ada manfaatnya.

Minimnya sanksi yang diberikan akibat keterlambatan atau tidak dibayarkannya pajak dari wajib pajak juga mempunyai pengaruh pada tingkatan kepatuhan hukum wajib pajak. Dimana wajib pajak tentu akan merasa tidak terikat dengan pajak akibat kewajiban pembayaran pajak dilalaikan. Selain itu, hal ini diperparah dengan kemakluman dari pemerintah sendiri sebagai pembuat regulasi pajak daerah. Sungguhpun batas toleransi keterlambatan dilampaui oleh wajib pajak. Hal ini tentunya juga mempunyai pengaruh besar terhadap PAD Kota Langsa, dikaitkan dengan pendapatan yang berasal pajak hotel dan restoran yang cenderung mempunyai pengaruh kecil dalam peningkatan PAD.

\section{E. PENUTUP}

Penerapan Qanun Kota Langsa No. 9 Tahun 2010 tentang Pajak Hotel dan Restoran mempunyai tujuan untuk meningkatkan PAD Kota Langsa melalui pajak hotel dan restoran dengan persentase $10 \%$ dari hasil penghasilan yang dihasilkan oleh hotel dan restoran. Merujuk pada hasil penelitian menunjukkan bahwa tingkat kepatuhan wajib pajak hotel setelah jatuh tempo pembayaran pajak masih sangat minim. Sungguhpun pihak Dinasi Pendapatan Kekayaan dan Aset Kota Langsa telah menghitung perhitungan awal potensi penghasilan daerah yang bersumber dari pajak hotel dan restoran cukup besar namun masih sangat kurang dalam peningkatan PAD. Faktor penyebab beberapa wajib pajak hotel tidak tepat waktu melakukan pembayaran dengan mekanisme self asessment adalah kurangnya omzet penghasilan yang diraih oleh pihak hotel. Sehingga pada saat dilakukan pendataan pajak hingga pembayaran pajak pada saat jatuh tempo tidak dilaksanakan sebagaimana mestinya. Selain itu, faktor lainnya adalah ketidaktegasan pemerintah Kota Langsa dalam penerapan sanksi bagi wajib pajak yang tidak melakukan pembayaran pajak. Hal ini tentunya berdampak pada tingkatan kepatuhan hukum wajib pajak dalam melakukan pembayaran pajak. Adapun realisasi pendapatan daerah yang bersumber dari pajak hotel masih sangat kurang berpengaruh dalam peningkatan pembangunan di Kota Langsa. Hal ini disebabkan penghasilan pajak 
e-ISSN : 2621-4105

hotel yang telah terhimpun pada kas daerah masih sangat minim. Sehingga program pemerintah dalam pembangunan dengan menggunakan dana kas bersumber dari pajak terasa sangat kurang untuk mendukung program pembangunan prioritas pemerintah sendiri.

\section{DAFTAR PUSTAKA}

\section{Buku}

Andrian Sutedi, “Hukum Pajak”, Sinar Grafika. 2011, Jakarta

Imam Soebechi, "Judicial Review Peraturan Daerah Pajak dan Retribusi Daerah"., Sinar Grafika, 2012, Jakata

Mardiasmo, “Otonomi dan Manajemen Keuangan Daerah”, ANDI, 2004, Yogyakarta. M. Djafar Saidi, "Pembaruan Hukum Pajak”, PT Raja Grafindo Persada, 2011, Jakarta.

Peter Mahmud Marzuki, "Penelitian Hukum”, Kencana, 2007, Jakarta

\section{Jurnal}

Atang Hermawan Usman, "Kesadaran Hukum Masyarakat Dan Pemerintah Sebagai Faktor Tegaknya Negara Hukum Di Indonesia”, Jurnal Wawasan Hukum 30 (1), 2014.

Ellya Rosana, "Kepatuhan Hukum Sebagai Wujud Kesadaran Hukum Masyarakat”, Jurnal TAPIs 10 (1), 2014 (https://doi.org/10.24042/tps.v10i1.1600)

Lucia Rita Indrawati, et., al., "Perspektif Pajak Daerah Bagi Pendapatan Asli Daerah Kota Magelan”, Jurnal Riset Ekonomi Pembangunan 2 (1), 2017.

(DOI: 10.31002/rep.v2i2.229)

Md. Krisna Arta Anggar Kusuma, Ni Gst. Putu Wirawati, "Analisis Pengaruh Penerimaan Pajak Daerah Dan Retribusi Daerah Terhadap Peningkatan PAD Se Kabupaten/Kota Di Provinsi Bali”, E-Jurnal Akuntansi Universitas Udayana 5 (3), 2013.

Mika Trisnawati, Wayan Sudirman, "Analisis Faktor-Faktor Yang Mempengaruhi Kepatuhan Wajib Pajak Membayar Pajak Hotel, Pajak Restoran Dan Pajak Hiburan Di Kota Denpasar", E-Jurnal Ekonomi dan Bisnis Universitas Udayana 12 (4), 2015.

Novi Andriani, Amin Purnawan, "Eksistensi Pengaturan Pajak Daerah Dalam Meningkatkan Pendapatan Asli Daerah Di Pemerintah Provinsi Jawa Tengah", Jurnal Hukum Khaira Ummah 12 (1), 2017.

Ni Made Intan Priliandani, Komang Adi Kurniawan Saputra, "Pengaruh Norma Subjektif Dan Sosialisasi Perpajakan Terhadap Kepatuhan Wajib Pajak Hotel Dan Restoran", Jurnal KRISNA: Kumpulan Riset Akuntansi 11 (1), 2019. DOI: https://doi.org/10.22225/kr.11.1.1158.13-25

Ronald Bua Toding, “Analisis Potensi Dan Efektivitas Pemungutan Pajak Hotel Dalam Meningkatkan Pendapatan Asli Daerah Kota Palangka Raya", Jurnal EMBA 4 (1), 2016. DOI: https://doi.org/10.35794/emba.v4i1.11588 
Yani Rizal, "Pengaruh Pendapatan Asli Daerah, Dana Alokasi Umum dan Dana Alokasi Khusus Terhadap Alokasi Belanja Modal Daerah Kota Langsa”, Jurnal Samudra Ekonomi dan Bisnis 8 (1), 2017.

DOI: https://doi.org/10.33059/jseb.v8i1

Yanto, Fatchur Rohman, Intan Ramadhanty, "Pengaruh Pemeriksaan Pajak, Omset, Dan Sanksi Perpajakan Terhadap Kepatuhan Wajib Pajak Hotel Dan Restoran Di Kabupaten Jepara", (2020) Jurnal KRISNA: Kumpulan Riset Akuntansi 11 (1), 2019. DOI: https://doi.org/10.22225/kr.11.1.1158.13-25

\section{Peraturan Perundang-Undangan}

Undang-Undang Nomor 44 Tahun 1999 tentang Penyelenggaraan Keistimewaan Propinsi Daerah Istimewa Aceh (Lembaran Negara Republik Indonesia Tahun 1999 Nomor 172, Tambahan Lembaran Negara Republik Indonesia Nomor 3893)

Undang-Undang Nomor 33 Tahun 2004 tentang Perimbangan Keuangan antara Pemerintah Pusat dan Pemerintahan Daerah (Lembaran Negara Republik Indonesia Tahun 2004 Nomor 126, Tambahan Lembaran Negara Republik Indonesia Nomor 4438);

Undang-Undang Nomor 11 Tahun 2006 Tentang Pemerintahan Aceh (Lembaran Negara Republik Indonesia Tahun 2006 Nomor 62, Tambahan Lembaran Negara Republik Indonesia Nomor 4633);

Undang-Undang Nomor 28 Tahun 2009 tentang Pajak Daerah dan Retribusi Daerah (Lembaran Negara Republik Indonesia Tahun 2009 Nomor 130, Tambahan Lembaran Negara Republik Indonesia Nomor 5049);

Qanun Kota Langsa No. 9 Tahun 2010 tentang Pajak Hotel dan Restoran (Lembaran Daerah Kota Langsa Tahun 2010 Nomor 9, Tambahan Lembaran Daerah Kota Langsa Nomor 280)

Qanun Kota Langsa Nomor. 4 Tahun 2012 tentang Pajak Daerah (Lembaran Daerah Kota Langsa Tahun 2012 Nomor 4, Tambahan Lembaran Daerah 324)

\section{Internet}

Rizki Maulana, Kemiskinan dan Ketimpangan Distribusi Pendapatan di Kota Langsa, http://rizkie-library.blogspot.co.id/2015/09/analisis-kemiskinan-danketimpangan.html, diakses pada tanggal 13 Februari 2018

Tahun 2017, Target PAD Kota Langsa Sebesar Rp124.092.504.605, https://www.goaceh.co/berita/baca/2016/11/24/tahun-2017-target-pad-kotalangsa-sebesar-rp124092504605, diakses pada tanggal 14 Februari 2018 